\title{
Cranial Meningocoele in a Crossbred Calf
}

\author{
Soundararajan $\mathrm{C}^{1 *}$, Chockalingam $\mathbf{P}^{2}$, Nagarajan $\mathbf{K}^{3}$, R Ananda Raja ${ }^{4}$ and M Arulprakash ${ }^{5}$ \\ ${ }^{1}$ Department of Veterinary Parasitology, Tamil Nadu Veterinary and Animal Sciences University, India \\ ${ }^{2}$ Cattle Breeding and Fodder Development Unit, India \\ ${ }^{3}$ Department of Veterinary Pathology, Madras Veterinary College, India \\ ${ }^{4}$ Central Institute of Brakishwater Aquaculture, Chennai, India \\ ${ }^{5}$ Veterinary College and Research Institute, India
}

Submission: April 20, 2018; Published: June 12, 2018

*Corresponding author: Soundararajan C, Department of Veterinary Parasitology, Madras Veterinary College, Tamil Nadu Veterinary and Animal Sciences University, Chennai - 600 006, Tamil Nadu, India. Email: drsoundarpara@gmail.com

Abstract

A 6 months old male Umblachery X Jersey crossbred calf with cranial meningocele was recorded.

Keywords: Cranial meningocoele; calf; Horses; Sheep; Pigs; Dogs; Cats; Buffalo; Iranian calves; Crossbred; Sucking; Muzzle; Jersey; Swelling

\section{Introduction}

Cranial meningocoele is a common congenital defect in cattle $[1,2]$. It also occurs in horses, sheep, pigs, dogs and cats [3-8]. The present paper report the occurrence of cranialmeningocoele in an Umblachery X Jersey crossbred calf.

\section{History and Clinical Observations}

A six month old male Umblachery X Jersey crossbred calf jersey calf with swelling on the forehead was examined at Thagattur village, Vedai taluk, Naapattinam district, Tamil Nadu. The calf was born at full term and had difficulty in sucking milk from the udder. Physical examination of the swelling revealed fluid filled and turgid inconsistency and situated on the cranial midline of the head, extending from the middle third of fore head to few centimetres above the muzzle. Puncture was made by using 16 gauze and two liters of colorless fluid was drained form the swelling and holes on the skull was observed on deep palpation after drainage.

\section{Results and Discussion}

In this study, swelling on the skull of a 6 months old male Umblachery X Jersey crossbred calf was identified as cranial meninocoele (Figure 1). A similar condition was reported in a buffalo calf and Jersey calf in Tamil Nadu [9,10], Meuse - Rhine - Yssel calf in Netherland [11] and in Iranian calves [12]. In the present case the meningocoele was observed in the frontal suture line arid covered by a normal skin. The herniations of fluid filled meninges through cranial defects were related to suture lines and were almost always median and usually in the frontal regions and covered by skin [13]. It may be caused by genetic or environmental factors or a combination of both [1]. Meningocole has been described as a failure of the neural tube to fuse shortly after conception $[14,15]$.

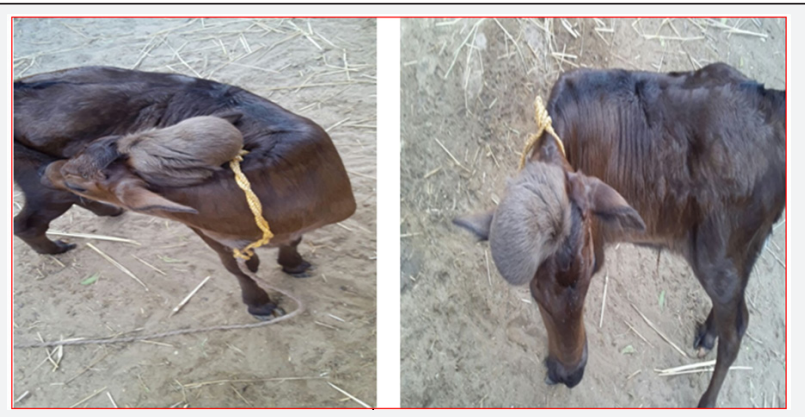

Figure 1: Cranial meningocoele in a crossbred calf. 


\section{References}

1. Leipold HW, Davis SM (1993) Congenital defects in cattle and sheep. In Current Veterinary Therapy, Howard JL, Philadelphia WB (Eds.), Food Animal Practice. Saunders, 3: 89.

2. Ohba Y, Fau-Iguchi T, Iguchi T, Fau-Hirose Y, Hirose Y et al. (2008) Computer tomography diagnosis of meningoencephalocele in a calf. Vet Med l Sci 70(8): 829-831.

3. Vogt DW, Ellersieck MR, Deutsch WE, Akremi B, Islam MN (1986) American Journal of Veterinary Research.47: 188.

4. Kohli RN (1998) Congenitalmeningocele with a rare skull defect in a lamb. Aust Vet J 76(4): 252.

5. Raoofi A, Dehghan MM, Mardjanmehr SH (2004) Cranium bifidum with meningocelein a lamb. Small Ruminant Research 55(1): 253-256.

6. Martle V, Caemaert J, Tshamala M, Van Soens I, Bhatti S et al. (2009) Surgical Treatment of a Canine Intranasal Meningoencephalocele. Vet Surg 8: 515-9.

7. Dewey C, Brewer D, Cautela M, Talarico L, Silver G (2011) Surgical Treatment of a Meningoencephalocele in a Cat. Vet Surg 40(4):473476

8. Mirshahi A, Seifi1 HA, Maleki M, Kazemi Mehrjerdi H, Halimi HA (2012) Three-Dimensional Computed Tomography Diagnosis of Cranium
Bifidum with Meningocele in a Lamb. Iranian Journal of Veterinary Science 7(1,2): 85-90.

9. Ayyappan S, Balasubramanian S, Subramanian S, Dhanapalan P (1996) Congenital Meningocoele in a buffalo calf - A Case report. Cheiron 25: $162-63$.

10. Justin William, Shiju Simon BM, Ayyappan S, Ramani C, Velavan et al. (2011) Surgical manaement of cranial meningocoele in a claf. Tamilnadu J Vet and Anim Sci 7: 164-166.

11. Back WA, Vanden Belt JM, Lagerweij, EVan Overbeeke JJ, Van der Velden M A (1991) Surgical repair of cranial meningocelein a calf. Veterinary Record 128: 569-71.

12. Kohli RN, Naddaf H (1998) Surgical treatment of cranial meningocele in Iranian calves. Vet Rec 142(6): 145

13. Maxie MG, Youssef S (2007) Malformations of the Central Nervous System. In: Pathology of Domestic Animals, Maxie MG (Eds.), ( $5^{\text {th }}$ edn), Elsevier, Saunders, 1: 301-302.

14. Oliver JE, Hoerlein BF, Mayhew IG (1987) Veterinary Neurology. Philadelpia. W.B.Saunders. pp. 194.

15. Jubb KVF, Huxtable CR (1993) Crania bifidaand related defects. In: Jubb KVF, Kennedy PC, Palmer N, (Eds.), Pathology of Domestic Animals, (4 $4^{\text {th }}$ edn), Academic Press, San Diego, USA 1: 273-74.

\section{Your next submission with Juniper Publishers will reach you the below assets}

- Quality Editorial service

- Swift Peer Review

- Reprints availability

- E-prints Service

- Manuscript Podcast for convenient understanding

- Global attainment for your research

- Manuscript accessibility in different formats ( Pdf, E-pub, Full Text, Audio)

- Unceasing customer service

Track the below URL for one-step submission https://juniperpublishers.com/online-submission.php 